\title{
Effects of Recognition and Job Promotion on Employee Performance of Commercial Banks in Kenya
}

\author{
Catherine Kathina and Hannah Bula \\ School of Business Administration, Kenyatta University, Nairobi, Kenya
}

\begin{abstract}
For the last one-decade, commercial banks in Kenya have been registering increased profits, however, the increase in labor turnover and increased cost of staff replacement has led to Kenyan commercial banks aggressively competing for competent employees. The study specifically sought to determine the effect of employee recognition and job promotion on employee performance in commercial banks in Kenya arising from a literature gap. This study used a descriptive research design using primary data, which was collected by use of semi-structured questionnaires. The study concludes that employee recognition and job promotion have positive and significant influence on employee performance in commercial banks in Kenya.
\end{abstract}

Keywords: job promotion, recognition, employee performance, employee motivation

DOI: $10.7176 / \mathrm{EJBM} / 13-8-05$

Publication date: April $30^{\text {th }} 2021$

\section{Introduction}

In modern corporate world, employees are regarded as asset and vital resource for the business in any organization. From designing to executing strategies and rules, employees are the fundamental ingredient. The success of a business is primarily affected by the conduct of the employees in the firm regardless of whether they are dealing with the clients directly or not (Alalade \& Oguntodu, 2015). Businesses that certainly understand the effect of their employees' performance can influence employee productivity and output. Properly governing employee performance helps an organization increase profits and continually meet set goals. One way of managing employees appropriately is by use of rewards.

There is need to have motivated employees in both private and public institutions due to the increasing demands of stakeholders, limited organizational resources, globalization, and the rapidly changing technology. In any organization, employees who are extremely stimulated are more effective, productive and are prepared to perform to achieve a company's objectives. Organizations are easily able to achieve and surpass set objectives when they have a set of highly inspired employees and this in addition gives them an edge over other organizations. These non-pecuniary rewards can be achieved through work promotions, awards and recognition, flexible work arrangement, career advancement, adjustable work schedules, among others. However, this study will focus on two non-financial incentives: employee's recognition and job promotion. Intrinsic rewards include the role intrinsic, intangible, and non-pecuniary rewards included in the position itself and may include roles and tasks, both challenging and interesting, not forgetting career development opportunities offered to the employees (Laakso, 2012).

\section{Non-Financial Rewards in Kenya}

In Kenya, organizations have also been rewarding employees both financially and non-financially. Imbahale (2016) revealed that incentives and rewards offer employee autonomy and make them feel appreciated and recognized for their output and contributions. The rewards make the workplace pleasant to work in, frill benefits such as leave, that is, extra days off for well performing employees, among other additional benefits. Kathure (2014) notes that employees work, and achievement of employee in setting goals can be largely influenced by career progress. Further, Kathure posit that sponsoring employee trainings to empower employees could to a great extent help in enhancing employee performance. Deficiency of training and skill growth initiatives almost in all cases results the management not being aware of the skill pool available to them and needed by the employees to perform. A conducive work atmosphere also plays an important role in uplifting morale hence productivity. Additionally, Ngatia (2015) notes giving employees more work and control of what they oversee, appreciation and acknowledgement for what they have done are form of reward and in general view enhances employee productivity.

Overall, non-monetary incentives are believed to inspire workers this in turn helps builds loyalty and dedication to the organizations that they serve which helps in achievement of objectives and improved job performance. This results in employees being interested and creates a happy, healthy environment, leading to work contentment which benefits firms and the employees. Promotion affects employee behaviours and encourages them to use their abilities positively so that they can move ahead (Pearce, 2011). Promotion encourages improved work performance; it is also used as a reward for good or of other approved behaviour in a firm. If hard work is rewarded by a promotion, then employees are likely to work harder. However, if the best job in the firm is often 
given to outsiders, then the employees will likely be less motivated towards working to achieve such jobs (Pearce, 2011). Through promotion firms can equate employees with the necessary ability, skill, or knowledge to successfully perform tasks with preference of the workforce to use the knowledge they have learnt (Njanja et al., 2013). A positive correlation exists between advancement opportunities and high level of job satisfaction. A promotion system that is efficient can increase employees' morale and increase firm efficiency.

\section{Problem Statement and Objective}

The profit-making trend has been the underline of Commercial banks' performance in Kenya have over the years, specifically, over the last five financial years several banks have reported low employee productivity and a reduction in efficiency (Central Bank of Kenya, 2016). Between the year 2015 and 2016 the number of staff in commercial banks in Kenya reduced by 7.46 per cent from 36,212 to 33,695. In addition, the number of staff reduced by 9.03 per cent between 2016 and 2017 to 30,903. Regarding efficiency score, on average, circa 2016, one employee was found to be serving 1,223 clients while in 2017 an employee was serving about 1,554 customers (CBK, 2017). As indicated by Bank Supervision report (2018), employee efficiency score increased from 1,544 in 2017 to 1,733 in 2018 . To put this into perspective, in 2018 , one employee was serving 1,733 customers while a year earlier an employee was serving 1,544 customers. However, some commercial banks experienced a decrease in employee performance in terms of efficiency and productivity. For instance, in Kenya Commercial Bank, employee productivity score reduced from $87 \%$ in 2017 to $83 \%$ in 2018 . Operation efficiency, which is related to the productivity of employees reduced from 51\% in 2017 to $48.3 \%$ in 2018 (Kenya Commercial Bank, 2018).

Commercial banks are investing heavily in reward programs whose sole goal is enhancing flexible work environment, facilitating career advancement, employee recognition as well as enhancing job promotion. Despite the investment put into these incentives and rewards, only a few of the employees can justify and substantiate whether they are efficient (Armstrong, 2010). Banks understand this logic and will offer pay benefits that are attractive to employees. However, employee performance is also affected by other factors with Tsuma (2015) explaining that in the long run financial rewards alone do not boost productivity and hence do not improve performance remarkable. Furthermore, according to Glassdoor Inc (2016) employee reviews on the bank, most of them complain over the lack of career growth pointing to poor job enlargement strategies. Regarding job recognition, the way the bank offers little to almost no form of job security is wanting.

In Kenya, various research has been done on non-pecuniary incentives and employee performance. For example, besides the study being limited to Kisii County, microfinance institutions are managed by diverse legal frameworks as compared to commercial banks. Gikuya (2014) examined on the same perceived relationship, however, his study was only limited to a marketing company where organizational structure, human resource needs as well as objectives and goals vary from those owned by commercial banks. The on-going research looks to examine influence of non-financial rewards on employee performance in Kenyan commercial banks.

\subsection{Objectives of the Study}

The overall objective was to determine effect of non-financial rewards on employee performance in Kenyan commercial banks with key objectives discussed here being:

i. To establish how employee recognition affects employee performance in Kenyan commercial banks.

ii. To assess effect of job promotion on employee performance in Kenyan commercial banks.

\section{Literature Review}

There have been several theories that have been brought forward that describe how reward on employee performance is essential tool. Theoretical background for this study will be is based on the Maslow's Needs Hierarchy theory, Vroom's Expectancy theory and The Psychological Contract Theory

According to Kreitner (2004), promotion should aim at recognizing the best talent in the firm such employees should be promoted to senior positions and promotion should also provide career advancement opportunities to employees according to the available opportunities and the employees abilities. Most employees evaluate themselves at a high level and feel that their work should be recognized.

Promotion is used for rewarding good performance, recognizes worker capabilities and used in firms as a staff development mechanism (Pousa \& Mathieu, 2010). It enables retention of employees as a laid down succession plan that is clear for the workforce, motivates them and encourages better performance and a long-term commitment to work for the organization. Employees who work for firms that use the promotion strategy also feel that they have job security. Satisfaction is also another benefit of promotion which leads to more loyal employees. When it comes to assessment of an employee's production in order give a reward or commendation, a working disclosure strategy must be put in place to evaluate what the employee who has not qualified for the appraisal is lacking and the measures that can be out in place to ensure they too become high performers (Wekesa \& Nyaroo, 2013).

Staff appraisals positively impact the morale and interaction on employees. Consideration of each staff 
member for a possible promotion should be the strategy used in any organization to maintain employee morale in job performance. The employer should know various employees' achievements as well as interests and provide skills building programs in various areas to assist employees move up (Mehta, 2014). Training and growth options should also be accessible to all staff members to raise the employees' intrigues and importance and urge them to take more liking to their work. Promotion also assists workers to grow themselves academically and gain new expertise. When devoted, hardworking and trustworthy employees are appraised by promotions, it helps them know that their efforts do not go unrecognized (Waqas \& Saleem, 2014).

In Dar es salaam City Council, Peter (2014) investigated the effects of promotions to employee performance. Case study plan was agreed upon for the research. The research observations indicated that DCC staff members were conscious of appraisal processes though there was the need for the HR department to communicate the plan better to the employees. Additionally, the findings indicated that promotion has effects to employee and company performance as it motivates, encourages good performance, improve relations as well as higher remunerations. The observations revealed there were effects for non-compliance to promotion strategies which impact personal achievements and organization, for instance poor relations, human resource turnover, decreased performance, and accumulated promotions. The study was performed in Dar es salaam city council, being a public institution and therefore these conclusions cannot be explicitly used in private sector and more so commercial companies like banks.

The top crème of any company is hard to keep, and these are also harder to find and onboard. Successful companies that do manage to keep these top performers have developed programs that recognize, appreciate, and reward the work done by these employees. According to Muli (2014), these programs can be formally structuring to provide financial incentive or just verbal recognition through open public forums like company events. The principle behind why this works is defined by the principle of positive reinforcement which creates a psychological inclination from employees that the rewards are likely to be repeated thus creating the urge within them to outperform each other thereby improving performance and aiding with retention (Aktar, Sachu \& Ali, 2012).

The reality is that many employers have dismissed these reward programs citing the fact that they have not measurable impact on profitability and have a high cost attached to them. Nevertheless, the study indicates that acknowledgment that varies from verbal appraisal and gifts that are not money related can be a cheaper remedy used to uplifting workers morale, decrease stress levels, increase the number of days present at work and summarily decrease staff turnover. Additionally, Abdullah and Wan (2013) indicates that the staff members are motivated through such plans and this leads to improved rates in terms of employee turnover this in turn helps employers benefit through high employee performance and lowered costs.

Bradler, Dur, Neckermann and Non (2014) assessed employee recognition and performance. This was an experimental study and At least 400 students were enlisted for work for three hours. Contributors performed their tasks individually on a data entry assignment in groups of eight people. The unmentioned provision of recognition (which was a thank you card) was given randomly after two hours of work. The results revealed that provision of rewards to all the participants in a group increased performance marginally. Surprisingly, a scarce reward methodology that only recognized the best performers in a category resulted to an increased performance. The study was conducted among students hired for a three-hour job and hence their findings would be different from those of real staff in commercial banks.

\section{Methodology}

As deduced by Russell (2013) an experiment that seeks to investigate the attitude of people, their attitude and conceptions regarding an issue requires the use of a descriptive based research design. A plan referring to a methodology group illustrating variables was used to gather data based on answered questions and interpreted to depict and describe the research findings.

This study targeted clerical, secretarial, supervisory, and managerial staff of Kenyan commercial banks. The number of these staff approximately covered the 30,903 employed and contractual staff of commercial banks within Nairobi, Kenya. This represents the selected individuals whose responses and observations are used to represent the greater population while a sampling technique basically defines the process of selecting the sample as shown in Table 1.

The key requirement in determining the size of a sample is that it must be representative of a population (Kothari, 2012). According to Creswell (2014) the chosen sample size must be able to provide enough data, good data that represents the population being studied. The formula is described below in detail.

$$
\mathrm{n}=\frac{\mathrm{N}}{\left(1+\mathrm{Ne}^{\wedge} 2\right)}
$$

whereby:

$$
\begin{aligned}
& \mathrm{n}=\text { sample numbers } \\
& \mathrm{N}=\text { targeted population }
\end{aligned}
$$




$$
\begin{aligned}
& \mathrm{E}=\text { error margin }(0.05) \\
& \mathrm{n}=30,903 /\left(1+\left(30,903 *\left[0.05 \rrbracket^{\wedge} 2\right)\right)\right. \\
& \mathrm{n}=394
\end{aligned}
$$

This research employed primary data, gathered through questionnaires that were semi-structured. These were used to gather the information from the four categories in the commercial banks. The test was done using a tenth of the sample respondents (39 individuals from Kenya Commercial Bank, Moi Avenue branch). Russell (2013) advises that for the pilot testing about a tenth of the sample size for the study be used and this group deduced through simple random sampling.

\section{Findings}

The sample size was 394 which included the management staff, supervisory staff, clerical as well as secretarial staff and support staff. The researcher disseminated 394 questionnaires during the process of data collection and 350 of the participants were able to completely fill as well as return the research tools to the researcher. Therefore, response rate was $88.9 \%$. As stated by the statements of Kothari (2009) a response rate is considered as sufficient for data analysis as well as reporting if it is above 50 percent whereas a response rate is classified excellent if it is above 70 percent. Hence, the study's response rate was within limits that are acceptable for making deductions and educated proposals.

\subsection{Employee Recognition and Employee Performance}

Respondents agreed that employee recognition is accompanied with some rewards. This is supported by aggregate mean of 3.794 (std. $\mathrm{dv}=0.901)$. Moreover, respondents also agreed that employer gives appreciation for a job well done as supported by an aggregated mean of 3.646, standard deviation of 0.216 . However, with an aggregated mean of 3.377, standard $d v$ of 0.151 , staffs were neutral that management sets a day of appreciating the best performing staff. Tampu (2015), points out that when good behaviour is immediately recognized, then this encourages its repetition.

With an aggregate mean of $2.123($ std. $d v=0.972)$, respondents disagreed that the employer involves all employees in decision making. In addition, with an aggregate mean of $2.206(\mathrm{std} . \mathrm{dv}=1.020)$ staffs also disagreed that management of the organization involves employees in problem solving. Further the respondents also disagreed that the management of the organization involves employees in all the phases of change. This is supported by an aggregated mean of 2.157 (standard $d v=0.887$ ) as shown in Table 2. Shazia, Tayyaba and Bilqees (2012) indicated generally a promising relationship between the management recognition and workers' morale building and achievements.

The staffs working in commercial bank agreed that employee recognition comes with increase in responsibility as supported by aggregate mean of 4.203 , std. dv of 0.723 . Further, staffs agreed that employer offers opportunities to reach high positions. This is supported by mean of 3.651, std. dv of 0.018 . Participants agreed with aggregate mean of 3.697 , std. $d v$ of 0.068 , that increase in responsibilities helps them gain more skills. Alam, Saeed and Akter (2013) revealed that staff members who achieve recognition tend to have a higher morale, selfesteem, a willingness to try out new work-related tasks and challenges, are more innovative and have higher confidence levels.

The staffs working in commercial bank were asked to specify in their opinion how else employee recognition influences employee performance in Kenya commercial banks. According to the study, the staffs revealed that behaviour recognition that promotes organizational goals improve employee performance and retention. Further, that the provision of rewards to employees increases performance marginally. The participants further revealed that workers, regardless of their level up the job ladder require their input and performance recognized by their employers or seniors.

Further it was indicated that staff members who achieve recognition tend to have a higher morale, self-esteem, a willingness to try out new work-related tasks and challenges, are more innovative and have higher confidence levels. Muchai and Mwangi (2014) revealed that acknowledgement of workers in one of the main employee interaction or engagement drivers thus employee acknowledgement is vital in the morale building and interaction. In addition, Alam, Saeed and Akter (2013) established generally a promising relationship between the management recognition and workers' morale building and achievements.

\subsection{Job Promotion and Employee Performance}

The fourth specific objective of outstanding indagation and inquiries was to assess the outcome as related to job promotion on employee performance in Kenyan commercial banks. The staffs working in commercial bank were required to specify their agreement level pertaining to job promotion. Findings were depicted in Table 3.

Staffs agreed that job promotion is accompanied by increase in responsibilities. This is supported by aggregated mean of 3.740, standard dv of 0.218 . Staffs also agreed with aggregated mean of 3.837 , standard dv of 0.148 that employee skills increase with job promotion. By aggregated mean of 3.917, standard dv of 0.136 , staffs 
agreed employees' ability increases with job promotion. Kreitner (2004) indicates that promotion should aim at recognizing the best talent in the firm such employees should be promoted to senior positions and promotion should also provide career advancement opportunities to employees according to the available opportunities and the employees abilities.

The staffs agreed with aggregate mean of 3.806, std. $\mathrm{dv}$ of 0.203 that change of facilities comes with job promotion. Additionally, with aggregate mean of 3.911 (std. $\mathrm{dv}=0.219$ ), participants further agreed that job promotion within the organization involves changing of offices. Staffs also agreed that job promotion comes with benefits such as access to a company vehicle. This is supported by an aggregated mean of 3.866 (standard dv $=$ 1.091). Shazia, Tayyaba and Bilqees (2012) argue that job promotion is always accompanied with benefits like company vehicles drivers bonus pay and holidays.

With aggregate mean of 3.63 , std. dv of 0.317 , the staffs agreed that job promotion comes with change of positions. Further the staffs agreed that change of positions leads to the requirement of new skills. This is supported by an aggregated mean of 3.771(standard $d v=0.204$ ). Alam, Saeed and Akter (2013) indicate that new positions are accompanied with increase in workload and require skilled personnel as well as innovation and creative employees.

The staffs working in commercial bank were requested to point out in their own opinion how job promotion impacts employee performance in Kenyan commercial banks. The respondents revealed that promotion encourages improved work performance; it is also used as a reward for good or of other approved behaviour in a firm. Further, the participants indicated that promotion enables firms to match their need for skilled employees with desire of the workforce to use the skills they have learnt. The participants also revealed that promotion should aim at recognizing the best talent in the firm such employees should be promoted to senior positions and promotion should also provide career advancement opportunities to employees according to the available opportunities and the employees abilities. Peter (2014) revealed that promotion has effects to employee as well as company performance because it motivates, encourages good performance, improved relations, as well as higher salaries. Further, Pousa and Mathieu, (2010) found that If hard work is rewarded by a promotion, then employees are likely to work harder. However, if the best job in the firm is often given to outsiders, then the employees will likely be less motivated towards working to achieve such jobs.

\section{Summary}

The study employed the use of descriptive survey with a sample size of 349 drawn from a target population of 30,903 . The response rate was $88.9 \%$ with $53.7 \%$ of respondents being between the age of $30-40$ years. $77.2 \%$ had achieved undergraduate education or higher whilst only $33.2 \%$ had worked for the commercial bank for more than 10 years. This meant respondents had experienced the different employee motivational endeavours from the commercial banking sector employers in Kenya. From the findings it was established that the organization offers appreciation for the job well done. It was found that employee recognition is accompanied with some rewards, however, the study established that the organization does not involve all employees in decision making. The study found that the management of the organization does not involve all employees in problem solving, furthermore, the study found that the management of the organization does not involve all employees in all the phases of change. Findings revealed that employee recognition comes with increase in responsibility and that the organization provides opportunities to get high positions.

The study found that job promotion has a positive and significant influence on employee performance in commercial banks in Kenya. From the findings it was found that job promotion comes with increase in responsibilities which demands more skills from the promoted employees. Moreover, findings revealed that employee's ability increases with job promotion since they face more challenging tasks which gives them enough experience. The study revealed that job promotion in the organization comes with benefits such as access to a company vehicle. Finally, it was established that change of positions leads to the requirement of new skills.

\section{Conclusion}

The study further concludes that employee recognition has a positive and significant influence on employee performance in commercial banks in Kenya. From the findings it was established that the organization offers appreciation for the job well done. In addition, the study established that employee recognition is accompanied with some rewards. However, the study found that the organization does not involve all employees in decision making. Further, the study found that the management of the organization does not involve all employees in problem solving.

The study concludes that job promotion has a positive and significant influence on employee performance in commercial banks in Kenya. From the findings it was found that job promotion comes with increase in responsibilities which demands more skills from the promoted employees. Moreover, findings revealed that employees' ability increases with job promotion since they face more challenging tasks which gives them enough experience. 
The main purpose of the study was to investigate the effect of non-financial rewards on employee performance in commercial banks in Kenya. However, the study was limited to commercial banks in Kenya. Therefore, the study recommends that further studies should be conducted on the effect of non-financial rewards on employee performance in other financial entities in Kenya. Besides that, the study found that $88.5 \%$ of the variation in independent variables (flexible work arrangement, career development, employee recognition and job promotion) could explain the dependent variable (employee performance in commercial banks in Kenya). Hence, the study recommends that further study should be conducted to assess other factors that influence employee performance in commercial banks.

\section{References}

Abdullah, A.A. \& Wan, H.L. (2013). Relationships of Non-Monetary Incentives, Job Satisfaction and Employee Job Performance. International Review of Management and Business Research, 2(4), 1085-1095

Aktar, S., Sachu, M. M. \& Ali, M. E. (2012). The impact of rewards on employee performance in commercial banks in Bangladesh: An empirical study. IOSR Journal of Business and Management, 6(2), 9-15.

Alalade, S.Y. \& Oguntodu, J.A. (2015). Motivation and Employees' Performance in the Nigerian Banking Industry: A Survey of Selected Banks. International Journal of Economics, Commerce and Management, 3(4), 36-49.

Bradler, C., Dur, R., Neckermann, S. \& Non, A. (2014). Employee Recognition and Performance - A Field Experiment. Retrieved from http://www.sole-jole.org/12118.pdf

Creswell, J.W. (2014). Research design. Qualitative, quantitative, and mixed methods approach. Thousand Oaks CA: Sage.

Imbahale, N.I. (2016). Effects of Non-Monetary Rewards Towards Employee Motivation (Doctoral dissertation, The Open University of Tanzania). Retrieved from http://repository.out.ac.tz/1755/1/Nancy_Imbahale_edited.pdf

Kathure, D. (2014). Influence of non-financial rewards on employee commitment at Kenya tea development agency. University of Nairobi. Retrieved from http://erepository.uonbi.ac.ke/bitstream/handle/11295/75621

Kothari, C. R. (2012). Research methodology: Methods and techniques. New Delhi: New Age International (P) Limited Publishers.

Kreitner, E. (2004). Management. 9th Ed. New York: Houghton Mifflin Company.

Laakso, L. (2012). Case study: the impact of financial and non-financial rewards on employee motivation. Retrieved from https://www.theseus.fi/bitstream/handle/10024/42808

Muli, J. V. (2014). Work Life Initiatives and Performance of Employees of Commercial Banks in Kenya. Retrieved from http://ir-library.ku.ac.ke/handle/123456789/10953

Ngatia, Z.M. (2015). The Influence of Non-Monetary Rewards on Employee Performance in Muranga Water and Sanitation Company, Murang'a County. Kenyar Retrieved from http://41.89.49.13:8080/xmlui/bitstream/handle/123456789/755/ZACHARY\%20\%20M.\%20NGATIA\%28 $1 \% 29 . p d f ?$ seq

Njanja, W. L., Maina, R. N., Kibet, L. K. \& Njagi, K. (2013). Effect of Reward on Employee Performance: A Case of Kenya Power and Lighting Company Ltd., Nakuru, Kenya. International Journal of Business and Management, 8(21), 18-23.

Pearce, J. (2011). Strategic Management Formulation Implementation and Control. 11th Ed Buxton: McGraw Hill.

Peter, C. G. (2014). Impact of promotion to employees performance At Dar es salaam city council. Retrieved from http://hdl.handle.net/11192/1180

Pousa, C., \& Mathieu, A. (2010). Sales Managers' Motivation to Coach Salespeople: an exploration using expectancy theory. International Journal Of Evidence Based Coaching \& Mentoring, 8(1), 34-50.

Mehta, A.M. (2014). Impact of Monetary Rewards on Employee Performance and Job Satisfaction (An Empirical Study of the Insurance Sector of Pakistan). Interdisciplinary Journal of Contemporary Research in Business, 5(11), 276-287.

Russell, R.B. (2013). Social research method: qualitative and quantitative approaches. Los Angeles: SAGE Publications.

Shazia, K., Tayyaba, Z. \& Bilqees, K. (2012). Effects of Recognition-based Rewards on Employees' Efficiency and Effectiveness. Journal of Management and Social Sciences, 7(2), 1-7.

Wekesa, J.N. \& Nyaroo, S. (2013). Effect of Compensation on Performance of Public Secondary School Teachers in Eldoret Municipality Kenya. International Journal of Scientific and Research Publications, 3(6), 23-29.

Waqas, Z. \& Saleem, S. (2014). The Effect of Monetary and Non-Monetary Rewards on Employee Engagement and Firm Performance. European Journal of Business and Management, 6(31), 23-29.Architecture for Holonic Manufacturing Systems: PROSA”, Computers in Industry 37(3), 255-274. 
Table 1. Targeted Population vs Sample Size

\begin{tabular}{lll}
\hline Staff Categories & Targeted Population & Sample Size \\
\hline Management & 10,298 & 131 \\
Supervisory & 6,188 & 78 \\
Clerical and Secretarial & 12,840 & 162 \\
Support Staff & 1,830 & 23 \\
Total & $\mathbf{3 0 , 9 0 3}$ & 394 \\
\hline
\end{tabular}

Table 2. Respondents results on Employee Recognition.

\begin{tabular}{|c|c|c|c|c|c|c|}
\hline 1 & 2 & 3 & 4 & 5 & Mean & Std. Deviation \\
\hline My employer offers appreciation for the job well done6.0 & 10.0 & 31.7 & 18.0 & 34.3 & 3.646 & .216 \\
\hline $\begin{array}{l}\text { Employee recognition is accompanied with some } 0.0 \\
\text { rewards }\end{array}$ & 12.0 & 16.9 & 50.9 & 20.3 & 3.794 & .901 \\
\hline $\begin{array}{l}\text { The management sets a day of appreciating the best } 10.0 \\
\text { performing staff }\end{array}$ & 6.0 & 38.6 & 27.1 & 18.3 & 3.377 & .151 \\
\hline My employer involves us in decision making 35.7 & 22.3 & 36.0 & 6.0 & 0.0 & 2.123 & .972 \\
\hline $\begin{array}{l}\text { The management of the organization involves us in } 33.4 \\
\text { problem solving }\end{array}$ & 22.9 & 33.4 & 10.3 & 0.0 & 2.206 & 1.020 \\
\hline $\begin{array}{l}\text { The management of the organization involves us in all } 26.6 \\
\text { the phases of change }\end{array}$ & 37.1 & 30.3 & 6.0 & 0.0 & 2.157 & .887 \\
\hline $\begin{array}{l}\text { Employee recognition comes with increase in } 0.0 \\
\text { responsibility }\end{array}$ & 0.0 & 18.0 & 43.7 & 38.3 & 4.203 & .723 \\
\hline $\begin{array}{l}\text { My employer provides opportunities to get high } 0.0 \\
\text { positions }\end{array}$ & 12.0 & 39.1 & 20.6 & 28.3 & 3.651 & .018 \\
\hline Increase in responsibilities helps me gain more skills 2.0 & 12.0 & 28.6 & 29.1 & 28.3 & 3.697 & .068 \\
\hline
\end{tabular}

Table 3. Respondents results on Job Promotion.

\begin{tabular}{llllllll}
\hline & $\mathbf{1}$ & $\mathbf{2}$ & $\mathbf{3}$ & $\mathbf{4}$ & $\mathbf{5}$ & Mean & Std. Deviation \\
\hline Job promotion comes with increase in responsibilities & 4.3 & 15.1 & 19.1 & 25.1 & 36.3 & 3.740 & .218 \\
Employee skills increases with job promotion & 5.1 & 8.6 & 18.6 & 32.9 & 34.9 & 3.837 & .148 \\
Employee's ability increases with job promotion & 5.1 & 8.9 & 11.4 & 38.3 & 36.3 & 3.917 & .136 \\
$\begin{array}{l}\text { Change of facilities comes with job promotion } \\
\text { Job promotion in the organization involves changing of6.0 }\end{array}$ & 6.0 & 10.0 & 17.7 & 30.0 & 36.3 & 3.806 & .203 \\
the offices & & & & & & \\
Job promotion in the organization comes with benefits5.4 & 8.6 & 20.0 & 26.0 & 40.0 & 3.866 & 1.091 \\
$\begin{array}{l}\text { such as access to a company vehicle } \\
\text { Job promotion comes with change of positions }\end{array}$ & 5.1 & 23.4 & 10.6 & 249 & 36.0 & 3.631 & .317 \\
Change of positions leads to the requirement of new skills6.0 & 8.9 & 23.7 & 24.9 & 36.6 & 3.771 & .204 \\
\hline
\end{tabular}

